\title{
Politologia
}

\section{Has the AfD changed German politics?}

\section{Klaus Ziemer}

Cardinal Stefan Wyszynski University in Warsaw

\section{Abstract}

The entry of the AfD to the Bundestag marks a new stage in German politics. This article traces the origins of this right-wing populist party against the background of extreme rightwing parties in post-war Germany. It analyses the main precepts of the party's programme and its activity in parliaments on the regional (Länder) level. A look at where AfD-voters are coming from reveals a long-term trend of a weakening alignment between voters and parties and a growing fragmentation of the German party system.

\section{Key words}

AfD, origins, party programme, AfD electorate, parliamentary activity

$\mathrm{T}$ he political scene in Germany is in a state of flux. The elections to the Bundestag in 2017 have, in a most remarkable way, continued the long-term change of the German party system. The entry of the right-wing Alternative für Deutschland (Alternative for Germany, AfD) reflects the changes in the political cleavages in Germany after the immigration crisis of 2015 and has brought about the end of unambiguous coalition alternatives on the federal level. The loss of votes by most of the established parties (the SPD got its worst result in Bundestag elections ever) and the number of parliamentary groups: six, which the Bundestag had last seen in 1953 - has made it clear that the Federal Republic is entering a new stage in its history. This was confirmed by the fact that the formation of a new government took half a year - an unprecedented long period of time in the history of the Federal Republic.

This article briefly addresses the history of the (West) German party system, with a special look at the parties of the extreme right, as well as at the changes in the relations between voters and parties. The main focus will be directed on the AfD. What was the origin of this party? Why 
did its leadership and its political orientation change so dramatically? What are the main precepts of its program? How is the AfD behaving in the regional (Länder) parliaments in which it has been sitting since 2014? Does the electoral success of the AfD mean a sudden 'turn to the right' of significant parts of the German electorate, and / or does the result of the Bundestag 2017 elections reflect long-term trends?

\section{The evolution of the German party system from 1949 to 2017}

After the first elections to the Bundestag in 1949 its splintered composition very much resembled the Reichstag of the Weimar Republic. Nine parties and four independent deputies seemed to reiterate the heterogeneous party system of the first German democracy. Only the SPD (with 29.2 percent of the votes) and the KPD (5.7 percent) were a direct continuation of Weimar parties. The most important new political grouping was the Christlich Demokratische Union Deutschlands (Christian Democratic Union of Germany, CDU) which united most of the Catholic Zentrum Party and parts of national-conservative Protestants. In Bavaria the Christlich-Soziale Union (Christian Social Union, CSU) continued the tradition of the Bavarian People's Party. Together the CDU/CSU received 31.0 percent of the votes. National and left liberals fused in the Freie Demokratische Partei (Free Democratic Party, FDP, 11.9 percent). Konrad Adenauer (CDU) headed the first federal government, a coalition of CDU/CSU, FDP and Deutsche Partei (German Party, DP), a national-conservative regional party in Lower Saxony.

The surprising concentration of the party system in the 1950 s was caused by several factors. The economic miracle attached many people to the new order (not necessarily to democracy), including even those Germans who had lost their homelands in former German territories and in East Central Europe. Only at the end of the 1950s, when the SPD fundamentally changed its economic program and options in foreign policy, there were clear political alternatives centred around CDU/CSU and SPD. The main cleavage concerned Western integration, which was favoured by Adenauer in order to safeguard political liberty against 
Soviet expansion, whereas the SPD was afraid that Western integration could delay German unification, if not make it impossible. There were charismatic politicians who facilitated political integration like Konrad Adenauer and Ludwig Erhard (CDU), the 'father of the economic miracle' or Kurt Schumacher (SPD). An 'institutional' factor that contributed to the concentration of the party system was the five percent threshold clause, which was introduced in 1956. From 1961 until 1983 only three parliamentary groups were in the Bundestag: CDU/CSU, SPD and FDP. The FDP was by far the smallest of these parties. Therefore many political scientists spoke of a 'two-and-a-half' party system. In the Bundestag elections of 1972 and 1976 these three parties received 99.1 percent of the valid votes, with a voter frequency of 91.1 and 89.7 percent respectively.

With the entry of the party Die Grünen (The Green Party) into the Bundestag in the elections of 1983 this two party system was replaced by a two bloc system - in the German political language, which associates parties with colours: a black-yellow bloc (CDU/CSU - FDP) vs. red-green (SPD and the Greens). This two bloc system was maintained after German unification, although the post-communist Partei des Demokratischen Sozialismus (Party of Democratic Socialism, PDS) formed a parliamentary club after the Bundestag elections of December 1990. However, the results of the Bundestag elections in 2005 created a situation that left no other viable alternative than forming a 'grand coalition' (CDU/CSU and SPD). This meant that the two bloc (or two camp) party system had been replaced by a 'fluid five party system' (Niedermayer 2008: 9) in a situation, in which no party wanted to enter into a coalition with the PDS. The electoral results of 2009 enabled a renewed 'black-yellow' coalition, but after the elections of 2013, when the FDP for the first time failed to cross the five percent threshold, once again the only possibility of forming a government was a new 'grand coalition', even though none of the partners wished it.

A new situation arose after the Bundestag elections of 2017, when the FDP returned to parliament and the AfD, founded in 2013, received 12.7 percent of the votes and became the third strongest party. For 
the first time since the 1950s six parliamentary groups have been sitting in the Bundestag. CDU/CSU received the second worst result in their history and the SPD - its worst result ever in Bundestag elections. Negotiations to form a 'Jamaica coalition' (black-yellow-green) failed after several weeks. Given this situation the Social Democrats, who had immediately after the elections declared their intent to form the opposition, nevertheless agreed to be part of a new 'grand coalition'. For the first time in the history of the Federal Republic forming a government lasted for half a year. However, the splintered composition of the Bundestag expressed deeper changes in German society. In the electoral result this was reflected by the fact that CDU/CSU and SPD had gained more than 90 percent in the Bundestag elections of 1972 and 1976, still maintained 69.4 percent in 2005 , but attained only 53.4 percent in 2017 .

\section{Declining relationships between parties and voters}

During the 1950 and 1960 s the core electorate of CDU and CSU consisted of voters who were closely connected especially with the Catholic Church, and to a lesser degree also with the Protestant churches. The SPD attracted most of its voters from the industrial workers' class, especially those organized in trade unions. The FDP represented the self-employed and liberal professions. However, from the 1970 os onwards deep ongoing economic and social changes had far-reaching consequences for the electorates of the parties. The 'Catholic milieu' was gradually fading away, as was the traditional working class (Lepsius 1993: 25-50). Society in general was economically better off and better educated, and the new middle class had no traditional party and was open to new values. After the 'revolution' of 1968, which in (West) Germany meant above all the calling into question of traditional authorities, student youth and the new middle class entered into politics. This could be seen in the formation, for the first time, of the first 'grand coalition' of CDU/CSU and SPD, which in the Bundestag had a majority of 90 percent. Since the ten percent of FDP deputies were not able to fulfil the tasks of a parliamen- 
tary opposition, a so-called 'anti-parliamentarian opposition' (APO) movement arose. A series of political demonstrations, happenings at universities, and other hitherto unknown forms of political expressions introduced new forms of unconventional political behaviour.

From the end of the 1960s to the 1980s the 'Ostpolitik' of the SPD provoked a political mobilization and polarization in society which caused an explosion of party membership - the SPD climbed from 732,446 members in 1968 to 1,022,191 in 1976, and the CDU/CSU from 360,166 in 1968 to 919,983 in 1983 (Niedermayer 2017). At the same time other forms of political participation which had already come into existence earlier, like social movements (for peace, anti-nuclear policies, for the environment) now gained in importance. The 'silent revolution' (Inglehart 1977) became apparent in West Germany and the Green movement, which was founded as a political party in 1980 encompassed not only ecological, anti-nuclear, new social movements and the new left of the 1970s, but also included currents calling for self-realization according to post-materialist values. In 1983 it entered the Bundestag, but for many years it was torn between the behaviour of a movement directed from and responsible to its base on one hand, and a professional parliamentary party on the other (cf. inter alia Jachnow 2013: 25-117).

The appearance of the post-communist PDS in the first elections to the Bundestag after German unification in 1990 marked a new stage in the evolution of the German party system. For a number of years thereafter East and West Germany maintained two different party systems. In West Germany the CDU and SPD were represented in all diets, and FDP and the Greens in most of them. In East Germany an alliance of civic movements and small parties ('Bündnis 90', Alliance 90) succeeded in entering the Bundestag in 1990 and fused with the Greens in 1993. In all the new federal states CDU, PDS and SPD were represented in the diets, but only rarely the FDP and the Greens. Given the social problems - especially unemployment - connected with the economic transformation, many people were preoccupied with safeguarding their economic survival so that there was only a small social base for a post- 
materialist party like the Greens or a party of liberal professions like the FDP.

In West German parliaments the PDS was not represented for many years. Only when the party merged with the left West German splinter party $\mathrm{WASG}^{1}$ in 2007 to form a new party Die Linke (The Left) did it succeed in entering most (but not all) of the West German diets. Thus a certain, but far from complete, convergence of the party systems in East and West Germany could be observed. In East Germany in several cases the Greens and the FDP entered some diets, but more remarkable was the electoral success of extreme right-wing parties like the Nationaldemokratische Partei Deutschlands (National-Democratic Party of Germany, NPD) or the Deutsche Volksunion (German People's Union, DVU) in several East German diets and on the local level.

\section{Extreme-right parties 1949-2018}

Parties of the extreme right existed from the very beginning of the Federal Republic. The Sozialistische Reichspartei (Socialist Reich Party, SRP), founded in October 1949, was dissolved by the Federal Constitutional Court in 1952 as a successor party of the NSDAP. A marginal Deutsche Reichspartei (German Reich Party, DRP, 1950-1965) demanded the restoration of the German borders of 1937 as a 'minimal solution'. Its greatest success was entering the diet of Rhineland-Palatinate in 1961 with 5.1 percent of the valid votes. A new attempt to establish an extreme rightwing party was initiated in 1964 with the founding of the NPD. The party recruited its leading personnel mainly from the DRP, but also from the remnants of the North German regional party DP, whose main leadership had fused with the CDU at the end of the 1950s, and from parts of the national-liberal wing of the FDP and politicians of an 'expellees'

1 The WASG (Wahlalternative Arbeit und soziale Gerechtigkeit, Electoral Alternative Work and Social Justice) had been founded as a club in 2004 by West German trade unionists and left-wing politicians who criticized the economic policy of the red-green government (Agenda 2010). In 2005 the WASG transformed into a (mini-) party. 
party which since the mid-1950s had largely been absorbed, especially by the CDU.

The NPD placed the 'nation', which was defined ethnically, at the centre of its programme and declared that Germany should regain a dominant role, at least in Europe. Having in mind the fate of the SRP, the NPD formally accepted the democratic principles of the constitution. The party's main orientation, however, proved to be historical revisionism: Germany had not caused World War II; there were no massive - if at all - German war crimes; and instead crimes were exposed whose victims had been Germans, and that Germany had to regain its prewar borders, etc. The party members belonged primarily to the middle class. In the Bundestag elections of 1965 the NPD received only 2.0 percent of the votes cast. In the immediate years to follow, however, the NPD took advantage of the first economic recession and entered seven of the eleven regional parliaments, with the best result in Baden-Württemberg in 1968 (9.8 percent). By the second half of the 1960 s it had some 25,000 members. However, the NPD failed, rather surprisingly, to cross the five percent threshold in the Bundestag elections of 1969 (gaining 4.3 percent). With the onset of an economic recovery and an unprecedented political mobilization at the beginning of the 1970 s (Ostpolitik), the NPD lost political importance and became a completely marginal party.

The most visible expression of extreme right-wing opinion was the weekly Deutsche Nationalzeitung with a circulation of about 100,000 copies, which propagated extremely revisionist judgements concerning World War II and demanded 'at least' German pre-war borders. In 1971 its owner, Gerhard Frey (1933-2013) founded the association Deutsche Volksunion (German People's Union, DVU) which in 1987 won - due to the regional electoral law - a seat in the 100-members diet of Bremen while garnering 4.3 percent of the votes. Four years later it won even 6.8 percent of the votes and five seats, possible because of its cooperation with the NPD, whose candidates received nominations on the DVU lists (Hertel 1998: 11). Following German unification the DVU had short-lived successes in a few East and West German regional elections - 
Schleswig-Holstein 1992 (6.3 percent of the votes), Brandenburg 1999 (5.3 percent) and 2004 (6.1 per cent), and in 1998 even 12,9 percent of the votes in Saxony-Anhalt. The members of the parliamentary groups of the DVU were, however, often not sufficiently qualified for their tasks and quarrelled among themselves, so that the DVU fractions as a rule disintegrated rather quickly. In 2011 the DVU ended its political activity as an independent organisation and joined the NPD.

Another rightist party which succeeded in entering parliaments were the 'Republicans', founded in 1983 by former CSU members. They made political gains from the wave of asylum seekers, whose numbers grew from less than 100,000 in 1987 to almost 440,000 in 1992, primarily because of the war in ex-Yugoslavia. This period coincided with the permission granted by the Soviet authorities for about two million Soviet citizens of German origin to leave the Soviet Union and relocate in Germany. The difficulties arising from these burdens, combined with a substantial East-West migration pattern within Germany after the fall of the Berlin wall, contributed to the electoral success of the Republicans, especially in Bavaria. They received 7.1 percent of the valid votes in the elections to the European Parliament in 1989 (in Bavaria itself they received more than 14 percent), and in regional elections they entered the parliaments of (West) Berlin in 1989 with 7.5 percent and in Baden-Württemberg with 10.9 percent in 1992 and 9.1 percent in 1996. When the article concerning asylum in the Basic Law was made more rigid in 1993 the attractiveness of this party dropped dramatically. In the Bundestag elections of 2013 it received only 0.2 percent, and in the elections of 2017 it did not start at all.

The good results of the NPD in East Germany following German unification were a surprise for many observers, given the often-repeated slogans by the GDR leadership that their state was 'anti-fascist' from the very beginning. In actuality an extreme-right skinhead milieu had developed in the GDR, which became visible in an attack of skinheads against a punk group and the audience in the Protestant Zion's church in East Berlin in October 1987, an incident which was also reported in the Western media (cf. inter alia Waibel 1996). According to a (secret) 
research group of sociologists and police detectives established after that incident, there were some 6000 persons known to be neo-Nazis, some 1000 of whom were considered to be prone to violence. In 1988 up to 500 acts of violence were noted each month, some of them directed against foreigners (from Mozambique, Poland, and Yemen) ${ }^{2}$.

Shortly after the fall of the Berlin wall, West German extreme right parties founded the first party groups in East Germany, which however did not succeed in reaching the five percent threshold in regional elections in the 1990s, except for the DVU (see above). Extreme right parties, especially the NPD, began to register an upward trend only with the enlargement of the EU to the East in 2004. In East Germany the unemployment rate that year was 18.4 percent. As a consequence of the accession of their countries to the EU, Poles and Czechs expected social advancement, whereas in Germany - in particular in the regions neighbouring the new member states - people were afraid of a descent down the social ladder and of unemployment. This especially concerned persons with low incomes and a low level of education (Rippl et al. 2007). Even though German politicians knew that such fears were unfounded they negotiated with the EU a seven-year transition period before there was free access to the labour market in Germany for citizens from new EU member states. Nevertheless in Saxony, which has a common border with Poland and the Czech Republic, the NPD received 9.2 percent of the valid votes in the regional elections of 2004, and 5,6 percent in 2009. In Mecklenburg-Western Pomerania, which is neighbouring Poland in the north, the NPD gained 7.3 percent in 2006 and 6.0 percent in 2011. The NPD did not return to either of these diets after the founding of the AfD, which received 9.7 percent in Saxony in 2014 - one year after the AfD was founded - (the NPD received 4,9 percent); and 20.8 percent in Mecklenburg-Western Pomerania in 2016 (with the NPD receiving 3.0 percent). The political marginalisation of the NPD was underscored by a decision of the Federal Constitutional Court in 2017.

2 Cf. Wagner, 2018. The author was a former police detective in the GDR and member of the aforementioned research group. 
It refused the delegalisation of the NPD (as demanded by the Federal Government and both chambers of Parliament), although it considered the political aims of the NPD as not compatible with the constitution. However, according to the Constitutional Court the political importance of the NPD was so insignificant that is was not worthwhile to dissolve it (Bundesverfassungsgericht 2017; Leggewie et al. 2017). On the other hand, the Bundestag and Bundesrat implemented a recommendation of the Constitutional Court that a party which is acting against the aims of the constitution should not be granted money from the state and accordingly changed the constitution (Gesetz zur Änderung des Grundgesetzes 2017). In the Bundestag elections of 2017 the NPD gained only 0.4 percent of the vote, short of even the threshold limit of 0.5 percent necessary to obtain state subsidies. As of 2018 it has only one deputy left in the EU parliament (the NPD in 2014 received only 1.0 percent of the vote). On the other hand, in the Bundestag elections of 2017 the AfD obtained its best results in Saxony, where the NPD had been strong before.

\section{The founding of the AfD and splits in its leadership}

It could hardly have been foreseen in 2013 that the founding of the AfD would have far-reaching consequences in German politics. The real origin of the party was the Euro-crisis and the fear that in the end Germany would have to pay the debts of the 'dissolute' members of the Euro-zone from Southern Europe. Several highly respected professors of economics, who formed the first executive board of the party, demanded that Germany should leave the Euro-zone, although not the European Union. Europe should consist of sovereign states with a single market. Competences, especially budget competences, should be returned to national parliaments. Other precepts of the first AfD program were reduction of the state deficit, more direct democracy according to the example of Switzerland, more support for families, and a sustainable concept for 'affordable' energy (Bundestagswahl 2013). The organizational basis of the party was a loose network of members from the CDU, FDP, small 
regional parties such as the Free Voters, and think tanks and lobbyists (Bebnowski 2015: 19-31).

The result of 4.7 percent in the Bundestag elections of 2013, only a few months after the AfD had been founded, was a remarkable success. In the elections to the European Parliament in May 2014 the AfD already garnered 7.1 percent of the valid votes. The political options of the seven AfD members elected to the EP reflected the political diversity of its leadership. Thomas Lucke, the first chairman of the AfD, was a liberalconservative professor of economics, as was Joachim Starbatty. HansOlaf Henkel had for many years been the head of the German Industry Federation. There were, however, also representatives of much more right-wing positions, such as Beatrix von Storch.

Following the AfD's electoral success in the 2014 elections to the European Parliament, it quickly became evident that the AfD was a party of very heterogeneous currents which were barely compatible with each other. The 'honourable' leadership of professors was surprised by the public statements of some party leaders, especially East German ones, which could be qualified only as ethnically national. This was in particular true for the AfD chairmen of Thuringia and Saxony-Anhalt, Björn Höcke and André Poggenburg. They belonged to the informal group Der Flügel (The Wing), which did not hide its extreme-right positions, whereas the chairwoman of the Saxonian AfD, Frauke Petry, represented rather national-conservative opinions.

One issue which made the intra-party conflicts more acute was the support of a considerable number of party members for the antiIslamic movement Pegida (Patriotische Europäer gegen die Islamisierung des Abendlandes / Patriotic Europeans against the Islamization of the West), which organized anti-Islamic and anti-immigration demonstrations in Dresden beginning in October 2014, always on a Monday, referring to the anti-communist Monday manifestations in autumn 1989 in the German Democratic Republic. These demonstrations were caused by a fear of the material and 'cultural' costs of hosting new Islamic immigrants in the vicinity of Dresden (Vorländer et al. 2016: 5-16), and for a couple of weeks led to similar manifestations in 
other cities as well, even in West Germany. From the very beginning these demonstrations were always accompanied by strong counterdemonstrations, whose numbers often exceeded those of the Pegida sympathisers. It is worth remarking that in several cities outside Dresden where such manifestations were initiated in 2016 church authorities switched off the illumination of the cathedrals, e.g. in Erfurt or Cologne, in order to eliminate the possibility that the Pegida sympathisers would have an 'attractive tourist' background which could be used to garner support for Pegida.

The Wing current published the Erfurt Resolution in March 2015 which declared AfD to be a 'basic, patriotic and democratic alternative' as compared to the 'established' political parties, and a 'movement of our people against the social experiments of the recent years' (e.g. gender mainstreaming, multiculturalism, etc.). It defined the AfD as a 'resistance movement' against the 'continued undermining of Germany's sovereignty and identity' (Die Erfurter Resolution, 2015). Five of the seven AfD EP-members criticised the racist, nationalist, antisemitic, anti-Islamic, homophobe, extreme right- and left-wing positions. However, during the turbulent party congress in Essen in July 2015 the moderate founding group lost their majority. Frauke Petry, leader of the Saxonian AfD, became the new chairwoman with a majority of 60 percent. Lucke and the other 'moderates' left the AfD and founded a new party, the Liberal-Konservative Reformer (Liberal-Conservative Reformers, LKR) which had no success in several regional elections and did not compete in the Bundestag elections of 2017. In the European Parliament the five LKR members belong to the fraction of European Conservatives and Reformers (ECR). The two AfD members had to leave the ECR fraction in 2016 after the AfD declared cooperation with the right-wing Freiheitliche Partei Österreichs (Freedom Party of Austria, FPÖ).

The AfD programme of 2016

The preamble of the AfD programme of 2016 seems to confirm the democratic principles laid down in the German constitution. In the first sentences the AfD even declares: 'we are liberals and conservatives. We are free citizens of our nation. We are staunch supporters of democracy'. 
A few sentences later, however, the programme refers to the key issue for supporters of the AfD: 'we maintain an open mind towards other nations and cultures, but wish to be and remain German at heart. Therefore, we shall continuously strive to uphold human dignity, support families with children, retain our western Christian culture, and maintain our language and traditions in a peaceful, democratic and sovereign nation state for the German people. Already in the introduction to the first chapter one can find slogans well known from right-populist movements, such as: 'at the latest since the Schengen (1985), Maastricht (1992) and Lisbon (2007) Treaties the inviolability of national sovereignty' has proven to be a 'fiction'. 'Behind the scenes a small and powerful elite (...) is secretly in charge', and there is 'a political class' and a power cartel, 'whose foremost interest is to retain their own power base'3.

The AfD is against a transformation of the European Union into a 'centralised federalised state'. It supports a Europe of nation-states. The European Union has taken over competences which had not been foreseen for it. Should it not be possible to reform the EU according to the intention of the AfD, Germany should leave it and try to refound the European Economic Community. The fact that a subchapter concerning the Euro is relatively long is probably due to the party's origin. The AfD calls 'for an end to the Euro experiment and its orderly dissolution'. If the Bundestag does not agree, there should be a referendum on this question. A referendum on the federal level is not foreseen in the German constitution, but the AfD wants to introduce to the German political system more elements of grassroots democracy, based on the example of Switzerland. The programme continues that 'membership of NATO corresponds to Germany's interests with regard to foreign and security policy, as long as NATO's role remains that of a defensive alliance. (...) The AfD rejects the idea of a combined European military force, and subscribes to well-equipped and trained German armed forces as the pillar of German sovereignty' (Manifesto

3 Manifesto for Germany 2016: 5-7. The Programme has been published on the Internet in German, English, French, Spanish, Russian, and Czech. 
for Germany 2016: 29-30). Although not included in the written party programme, in public declarations party leaders support good relations with Russia. Alexander Gauland in this context even referred to Bismarck (Carstens 2013; Bockenheimer 2016). The AfD is one of Russia's lobbyists in Germany and condemns the economic sanctions against Russia. In August 2017 it even organized a 'Russian Congress' in Magdeburg (Bender 2017).

Crucial chapters in the programme are dedicated to questions of language, culture, and immigration. The ideology of multiculturalism is rejected, because it depreciates German culture, which should be predominant. 'The AfD believes that the link between education, culture and identity is of paramount importance for the development of society'. The German language should be declared as the official language and enacted as such into the constitution. The AfD acknowledges that many integrated Muslims are living in Germany, but insists - quoting an oftenrepeated slogan - that the Islam 'as such' does not belong to Germany. Financing of mosques by Islamic states or by money of foreign origin should be forbidden. Imams who want to work in Germany should have to obtain an authorisation from the government and have to preach in German.

Persons who are persecuted in their home countries for political reasons or because of war should be able to obtain asylum in Germany for as long as the situation in their country is going on. After that they have to return. The EU has to close its external borders completely. In 'safe' countries of the regions where the immigrants are coming from, e.g. North Africa, shelter and asylum centres should be established under UN and EU mandates. 'People seeking protection are expected to claim asylum only in those centres. People claiming asylum in Germany and the EU are to be urged to return to those centres without exception' (Manifesto for Germany 2016: 58). Criminal acts committed by immigrants must be published without improper political correctness. The 'invasion' into the German social systems by immigrants from other EU member states must be avoided by changes in the German legislation. 
In this programme, the AfD showed its right-populist orientation much more openly than in previous documents. It criticised the 'political elites' and the 'political cartel' not only in Berlin, but also in Brussels, as consisting of persons who cared only for themselves, at the cost of ordinary people. And it pretends to know what the interests of 'the people' are. Finally, its aim is to safeguard the alleged cultural homogeneity of the German people, which is endangered especially by a growing Islamic community in Germany (Rosenfelder 2017: 123-140). Although not in the program, in daily practice an element aimed at strengthening German identity and pride is a revisionist history policy, albeit it is not labelled in this way by AfD politicians. In a notorious speech, the AfD chief of Thuringia, Bernd Höcke, who was born and grew up in West Germany, during an event, organised by the AfD youth in Dresden on 17 January 2017 claimed that former presidents of the Federal Republic, like Richard von Weizsaecker (8 May 1985 in the Bundestag) or Roman Herzog had held important speeches which were, according to Höcke, directed against the German people. The often-quoted key sentence of Höcke's speech was: 'we Germans are the only nation in the world which has erected a monument of its shame in the heart of its capital'4. The co-chief of the AfD and probably most influential AfD politician, Alexander Gauland (born in 1941, until 2013 a member of the CDU, and between 1987-1991 head of the minister president's office in Hessia) confirmed the revisionist view of German history. In a speech in September 2017 he said that no other nation had confirmed such a 'wrong history' as the Germans. The twelve years of national socialism 'no longer affect our identity'. If the French are proud of Napoleon or the Britons of their 'war prime minister Churchill, we have the right to be proud of the accomplishments of German soldiers in the two world wars' (Gauland provoziert 2017). During a meeting of the AfD youth

4 This was an allusion to the 'monument for the murdered Jews of Europe' near the Brandenburger Tor and the Bundestag; cf. the documentation of Höcke's speech in: Höcke-Rede im Wortlaut: 'Gemütszustand eines total besiegten Volkes', 19.01.2017, available at https://www.tagesspiegel.de/politik/hoecke-rede-im-wortlaut-weizsaeckers-rede-zum-8-mai-1945-war-gegen-das-eigene-volk/19273518-3.html. 
organization on 2 June 2018 he declared that the twelve years from 1933 to 1945 were, when seen against the background of the 'magnificent' thousand years of German history, mere 'bird droppings' (Bei AfDJugendorganisation 2018). Following massive criticism by the German public, Gauland said that his statement had been 'politically unwise' (Gauland bezeichnet 2018).

\section{Where does the AfD electorate come from?}

The astonishing rise in the electoral results of the AfD from the year of its founding in 2013 until today make it look like a success story. The AfD is represented in all regional parliaments with the exception of Bavaria and Hessia, but according to all the opinion polls it will be represented there, too, following the elections to be held there in October 2018. One can observe a clear East-West divide in these results, including in the Bundestag elections of 2017.

Table 1: AfD results in regional elections 2013-17 (in percent)

\begin{tabular}{|c|c|}
\hline Old federal states & New federal states \\
\hline Hessia 2013: 4.1 & Saxony 2014: 9.7 (NPD 4.9) \\
\hline Hamburg 2015: 6.1 & Brandenburg 2014: 12.2 \\
\hline Bremen 2015: 5.5 & Thuringia 2014: 10.6 (NPD 3.6) \\
\hline \multicolumn{2}{|l|}{ Baden-Württemberg 2016: 15.1} \\
\hline \multicolumn{2}{|l|}{ Rhineland-Palatinate 2016: 12.6} \\
\hline \multicolumn{2}{|c|}{ Berlin 2016: 14.2} \\
\hline West Berlin 12.1 & East Berlin 17.0 \\
\hline Saarland 2017: 6.2 & Saxony-Anhalt 2016: 24.3 \\
\hline Schleswig-Holstein 2017: 5.9 & $\begin{array}{l}\text { Mecklenburg-Western } \\
\text { Pomerania 2016: } 20.8 \\
\text { (NPD 3.0) }\end{array}$ \\
\hline North Rhine-Westphalia 2017: 7.4 & \\
\hline
\end{tabular}

Source: Own compilation according to official electoral results, available at https://wahl. tagesschau.de/landtag.shtml. 
Table 2: AfD results in the Bundestag elections of 2017 (in percent)

\begin{tabular}{ccc}
\hline & Federal Republic \\
\hline & 12.6 & \\
\hline $\begin{array}{c}\text { West Germany } \\
\text { and West Berlin }\end{array}$ & & East Germany \\
10.7 & and East Berlin \\
& Berlin & \\
\hline West Berlin & 12.0 & East Berlin \\
10.1 & & 14.8 \\
\hline
\end{tabular}

Source: Own compilation according to official electoral results, available at https://wahl. tagesschau.de/wahlen/2017-09-24-BT-DE/index.shtml.

How can one explain this spectacular success of a right-populist party? Are supporters of extreme right-wing positions growing rapidly in Germany, and what explains the East-West divide? A first explanation can be given by the results of a research group at the University of Leipzig. Since 2002 they have carried out empirical studies concerning extreme right-wing attitudes in Germany every two years. One of the reasons behind the commencement of these studies had been the pogroms against fugitives and immigrants in the 1990 s. The authors referred to classic studies by Theodor Adorno and others on authoritarian personality (Adorno et al. 1950: 744-783) and adapted them to Germany's actual problems. They developed a set of six items: acceptance of a right-authoritarian dictatorship; chauvinism; hostility towards foreigners; antisemitism; social Darwinism; downplaying national socialism. If persons agreed to all six items the researchers spoke of a 'closed extreme-right world view'. The results of their studies were quite surprising. There were, for example, at the beginning of the 2000 s more persons with an extreme-right ideology in West than in East Germany. There was a permanent change in the attitudes, not only concerning the 'closed extreme-right world view', but also concerning each of the six items (Decker, Kiess, Eggers and Brähler 2016: 43-47). 
Table 3: Persons with an extreme-right ideology 2002-16 (in percent)

\begin{tabular}{lcccccccc}
\hline & 2002 & 2004 & 2006 & 2008 & 2010 & 2012 & 2014 & 2016 \\
\hline Germany & 9.7 & 9.8 & 8.6 & 7.6 & 8.2 & 9.0 & 5.7 & 5.4 \\
\hline East & 8.1 & 8.3 & 6.6 & 7.9 & 10.5 & 15.8 & 7.4 & 7.6 \\
\hline West & 11.3 & 10.1 & 9.1 & 7.5 & 7.6 & 7.3 & 5.2 & 4.8 \\
\hline
\end{tabular}

Source: Figures according to: Decker, Kiess, Eggers and Brähler 2016: 48.

The rise of extreme-right attitudes in East Germany in 2012 is explained by the difficult economic situation, which improved by 2014 . At first glance the surprising trend is that extreme-right attitudes have diminished during the last few years.

This is confirmed, at least partly, by another study in the same project. The researchers divided society into three main political milieus, including some sub-categories, as follows: democratic milieu; milieu with prejudices, but relative acceptance of the existing system; and antidemocratic-authoritarian milieus. Their evolution between 2006 and 2016 showed a similar direction as the extreme-right attitudes in Table 3. A consolidation of democratic attitudes could be observed here, too.

The milieus with reservations and the authoritarian milieus have diminished, while the democratic milieus have grown from 36,9 to 60 percent. The antidemocratic milieus were subdivided in 2006 and 2016 according to three characteristics: 'strong prejudices (manifest / latent), relatively great willingness to authoritarian aggression, especially pronounced loss of confidence in the democratic system. The decline of the three antidemocratic milieus from 41.7 to 26 percent seems to be paradox, given the evident rise of extreme-right behaviour in the public. 
Table 4: Political milieus in Germany in 2006 and 2016 (in percent)

\begin{tabular}{llcc}
\hline & & 2006 & 2016 \\
& & & \\
& & & \\
\hline & Modern milieus & $23.872)$ & 30.6 \\
\hline Democratic milieus & Conformist milieus & 13.6 & 29.3 \\
\hline $\begin{array}{l}\text { Milieu with reservations, } \\
\text { but relative acceptance } \\
\text { of the existing system }\end{array}$ & Milieu with reservations & 21.5 & 14.1 \\
\hline $\begin{array}{l}\text { Antidemocratic- } \\
\text { authoritarian milieus }\end{array}$ & $\begin{array}{l}\text { Hidden antisemitic- } \\
\text { authoritarian milieu }\end{array}$ & 17.5 & 8.4 \\
\hline & $\begin{array}{l}\text { Ethnocentric-authoritarian } \\
\text { milieu }\end{array}$ & 12.8 & 10.3 \\
\hline & $\begin{array}{l}\text { Rebellious-authoritarian } \\
\text { milieu }\end{array}$ & 11.4 & 7.3 \\
\hline
\end{tabular}

Source: Decker and Brähler 2016: 104.

A possible explanation for this paradox is given in another study of 2016. Extreme-right positions had been visible in all studies since 2002, but most of these persons refused to vote NPD because they considered themselves to be part of the 'middle of society' and not part of a 'margin'. In 2014 almost 50 percent of this group still voted for CDU/ CSU and SPD. In 2016 this figure dropped to 26.4, whereas 34.9 percent preferred the AfD (26.4 percent non-voters) (Brähler, Kiess and Decker 2016: 78). The AfD seems to have become an acceptable political offer for middle class voters. It openly speaks about what many people are thinking about burning questions like asylum, immigration and other problems, without respecting political correctness. AfD leaders several times have broken taboos, concerning for instance the national-socialist past. After being on the receiving end of vehement criticism they declared they had been misunderstood, but the taboo was broken and the next time they could go even further. This concerns also the critique of the mainstream media as a 'lying press'. Asked in the opinion poll of 2016 if they personally would speak of 'lying press' (Lügenpresse), 41.3 percent of the AfD supporters said yes, while only 10,5 percent 
said no. In contrast, only 10.1 percent of the supporters of the SPD answered yes, while the same (yes) percent figures for CDU/CSU were 8.7, and for the Greens 6.0 and FDP 4.0. Only 11,1 percent of AfD voters agreed with democracy the way it is being practiced (the same figure for $\mathrm{CDU} / \mathrm{CSU}$ was 70.2 percent). AfD received the highest support when items referred to 'threatened German identity' and anti-immigration slogans; 80.3 percent of the AfD voters agreed that Muslims should be forbidden to immigrate to Germany (the same figure for the Greens was 23.5 percent) (Brähler, Kiess and Decker 2016: 67-94).

The findings of the 'Mitte-Studien' that right-populist voters are coming from the 'centre' of society have been confirmed by the Populismusbarometer 2018 research project carried out by the Bertelsmann Foundation and the Wissenschaftszentrum Berlin, presented in autumn 2018. The representative data were collected in two waves during May / June and August 2018 among 3,247 and 3,323 respondents respectively. According to these results 30.7 percent of the Germans eligible to vote have a populist attitude (2017: 29.2 percent), while 12.7 percent have populist views and consider themselves as belonging to the centre. On the other hand the percentage of explicitly non-populist voters dropped from 37 to 32.8 , whereas the proportion of persons answering yes and no increased from 33.8 to 36.8 percent. The authors found that 'people with right-wing orientation vote for the AfD because it is right, voters from the middle vote for AfD because it is populist', and therefore speak of populism as 'a kind of Trojan horse of the right-wing party AfD in the political middle' (Vehrkamp and Merkel 2018: 11). Richter and Bösch, who stress the fact that the AfD gained its best results in the Bundestag 2017 elections in places where in previous elections the NPD had obtained its best results (especially in Saxony), call the AfD in this context 'NPD light' (Richter and Bösch 2017: 4).

People prone to support the AfD have attitudes which in several regards differ significantly from the rest of German society. In a compilation of recently conducted opinion polls by several renowned institutes, on 1 September 2018 Bild-Zeitung published new data on 
the social background of AfD voters. It had often been supposed that AfD followers are losers in terms of their social and economic development. An Insa study reveals, however, that they have a net monthly income per household of more than 3000 Euros, i.e. on a level of the average income in Germany. What differs however is that they have a clearly more pessimistic view concerning future economic development in Germany, with 71 percent of AfD supporters thinking it will worsen. Of the non-AfD followers in the whole of Germany only 38 percent think so. More than half of the AfD supporters (52 percent) are not content with the democratic political system as established by the basic law (constitution), while among the rest of society the same figure is 20 percent. Also, 49 percent of AfD supporters define themselves as belonging to the political right. Only 27 percent of AfD followers are women and 73 percent are men, and 56 percent of AfD supporters do not have a religious affiliation.

The criterion which probably most differs AfD supporters from the rest of German society is their attitude towards 'strangers', with 77 percent of them declaring that immigration is causing fear. This attitude is shared by only 22 percent of non-AfD followers in Germany ${ }^{5}$. The statement that Germans have 'to fight for their country', because 'fugitives are bringing unrest and violence to our country' is agreed to by 59 percent of the AfD followers, but only by 8 percent of the non-AfD supporters. Thirty nine percent of AfD followers stated that they experienced material disadvantages because of the 'fugitives'. Among the persons who do not support AfD only 7 percent felt the same way. Those people who are in favour of a 'culture of welcome' or 'multi-culture' are considered by 51 percent of the AfD followers to be 'traitors to the fatherland' (Wer die Rechtspopulisten wählt 2018).

However, the potential of the AfD is not unlimited. No other party meets with such a high degree of objection, as shown in Table 5 below.

5 In Saxony regional elections will be held in 2019. In August 2018 the AfD had its highest score among all federal states in Saxony, obtaining 25 percent of the total votes, only three percentage points behind the CDU. 
Table 5: 'Which party would you never vote for?' (2018, in percent)

\begin{tabular}{cccccc}
\hline AfD & The Left & Greens & FDP & CDU/CSU & SPD \\
\hline 71 & 51 & 31 & 29 & 29 & 23 \\
\hline
\end{tabular}

Source: Vehrkamp and Merkel 2018: 17.

For the time being one conclusion can be drawn from several studies. The extreme-right supporters are diminishing in number, but radicalising in behaviour. This could be observed during the summer of 2018, especially in Saxony whose authorities often had been criticised for underestimating the willingness of the extreme-right scene to engage in violence. After a German was presumed to have been killed by two immigrants at the end of August in Chemnitz, about 50 extreme-right activists and hooligans ready for violence led a demonstration of 800 people, shouting slogans against foreigners and even threatening them with murder. A Jewish restaurant was also attacked. This event seemed to be a signal for extreme-right activists from other parts of Germany to go to Chemnitz, where police only gradually managed to get control over the right-wing demonstrators and counter-protesters.

The reaction of state authorities to the events in Chemnitz made things even worse. Although on the Internet there was a short film which showed several people running to seize a dark-skinned man, the president of the Federal Office for the Protection of the Constitution, Hans-Georg Maaßen, denied that there had been a 'hunt'. Maaßen, who had already been criticised for having met some leading AfD politicians during the previous months, was supported by Horst Seehofer, chief of the CSU, who as Minister of the Interior was Maaßen's superior authority. On the other hand Angela Merkel, chief of the CDU, spoke openly of a 'hunt' and the SPD demanded that Maaßen should lose his office. The 'solution' found, in order to save the 'grand coalition' was a classic example of an elite taken over the heads of the 'base' and further fuelled populist moods: Maaßen was stripped of his office and was supposed to be given the job of a secretary of state to Seehofer's Ministry of the Interior, with an increase in his salary of 2500 Euros a month. 
After fierce protests from the SPD base, which demanded an end to the 'grand coalition', Maaßen in the end became head of a specially created department in the Ministry of the Interior with the same salary as in his previous position ${ }^{6}$. It is not that the governing parties lost support over this incident, while the AfD slightly improved its position and in some opinion polls even surpassed the SPD ${ }^{7}$.

On the other hand, on 1 October 2018 police in Saxony and Bavaria arrested eight men who were accused of having formed an extreme-right terrorist group called Revolution Chemnitz. This group was said to have planned armed attacks against foreigners, politicians, journalists and other people in order to unleash a civil war two days later, on Germany's national holiday of 3 October. If these accusations turn out to be true this would be another proof that, especially in Saxony, a militant and violent extreme-right milieu has formed. At the same time, here as elsewhere in Germany one can also observe impressive counter-manifestations against antidemocratic and xenophobic behaviour. In Hamburg, on 5 September 2018175 right-wing activists (shouting 'Merkel must go') were confronted by 10,000 counter-demonstrators (Exner 2018). A very clear position has been taken by representatives of the churches. After the events in Chemnitz the archbishop of Cologne, Cardinal Rainer Maria Woelki, condemned extremism, stating that 'xenophobia, hatred, violence, Nazi slogans and the 'Hitler salute' have no place in democracy'. People who make a common cause with 'hordes of the extreme right' are 'accomplices and no 'alternative for Germany" (Wochenimpuls 2018). The president of the central committee of German Catholics, Thomas Sternberg, saw parallels between the AfD and the national socialists. In the final period of the Weimar Republic there had also been a party (NSDAP) which had taken outrageousness into parliaments. The AfD has always been a movement gathering various forces, but in recent

6 After a scandalous speech delivered during a meeting with former colleagues from other EUstates, Maaßen was finally dismissed by Seehofer in November 2018.

7 Cf. the results of an EMNID opinion poll as of the end of September 2018: CDU/ CSU 27 percent, AfD 17, SPD 16, Greens 15, the Left 11, and FDP 10 percent; AfD überholt die SPD, 2018. 
times it has radicalised unambiguously. Party chief Alexander Gauland is serving an extreme right-wing clientele and leading an extreme right-wing party. Before the elections to the diets in Bavaria and Hessia (in October 2018), Sternberg called for an overall resistance by all free democratic forces against AfD (Katholiken-Präsident 2018).

The fact that 'after Chemnitz' several politicians demanded an observation of the AfD by the Federal Office for the Protection of the Constitution seemed to alarm AfD politicians. The extreme-right AfD-'Patriotic Platform' declared that it would dissolve itself because its aims had been achieved. The AfD youth organisations in Lower Saxony and Bremen, which were supposed to be subject to observation, have declared that they are going to dissolve themselves, too. The frightened party leadership is considering the establishment of internal controllers whose task will be to examine the extreme right margin of the party (AfD will Beobachtung verhindern 2018). Several liberal-conservative AfD-deputies on the regional level have left the party in 2018. This will, however, hardly end the AfD-leadership's acceptance of, or at least tolerance of, close cooperation of the party's right wing with milieus of the extreme right.

\section{Parliamentary activity of the AfD}

It is still too early to assess the parliamentary work of the AfD since no regional parliament to which it entered has finished a full term yet, and it has only been in the Bundestag for a year now. An empirical study on the behaviour of AfD deputies in ten regional parliaments from July 2017 draws an ambivalent balance. There are two types of fractions. One is oriented more towards parliamentary work, trying to be a 'constructive opposition' on the right, beyond the CDU. The other type is characterised as a 'movement-oriented type', whose parliamentary behaviour rather aims at changing the political culture by breaking taboos. The AfD fractions lay twice as much more stress than others on issues such as asylum, migration, and integration. In parliamentary committees the level of participation of AfD deputies is significantly 
lower than that of other deputies. Plenary discussions, however, are used in order to communicate the party's core issues via social media to their own members and supporters, with the aim of mobilising them. The other parties have predominantly chosen a strategy of arguing with the AfD instead of isolating it, so that the AfD cannot claim to be a 'victim' (Schroeder et al. 2017).

In the Bundestag 2017 elections the AfD gained the third best result and 92 seats, and in Saxony even direct seats in three constituencies ${ }^{8}$. Only ten of the 92 deputies are women. The numerical strength gives the party a powerful position. After CDU/CSU and SPD formed their new 'grand coalition' the AfD is the largest opposition party, and possesses certain formal and informal rights in parliamentary practice. It has, for instance, the right to be the first fraction to answer a statement by the government. Financially each deputy (as every deputy of the Bundestag) is entitled to spend 20,870 Euro a month for personal staff in Berlin and / or in the office in their electoral constituency. The AfD fraction is said to be planning 150 jobs for supporting its parliamentary work. Altogether it is estimated that the $\mathrm{AfD}$ can create several hundred jobs with a volume of about 200 million Euro a year (Gürgen et al. eds. 2018: 3). However, only a very few AfD deputies possess parliamentary experience ${ }^{9}$ and most still have to get acquainted with parliamentary routine.

Given the reservation of the mainstream media towards the AfD, its Bundestag fraction has since April 2018 established a 'news room' from which it aims to inform its own target groups without 'distortions' by the mainstream media. For this task the fraction plans to employ up to 20 persons who are to serve especially in social media, which already in several previous electoral campaigns has successfully been used by

8 The AfD won 94 seats. The day after the election the formal party leader Frauke Petry left the party, whose leadership she considers to be too right-wing. She and another deputy elected on the AfD ticket are Bundestag members not belonging to a parliamentary club.

9 One of them is Martin Hohmann, who in 1998 and 2002 was elected to the Bundestag as a CDU member. After an antisemitic speech in October 2003 he was excluded from the party in 2004. He has now returned to the Bundestag as an AfD deputy. 
the AfD more intensively than by other parties. Steve Bannon, who previously closely cooperated with Donald Trump, is to be engaged as an advisor (Ruhose 2019: 36).

The first quantitative studies of the AfD's parliamentary activities during the first year of its presence in the Bundestag have shown that its priorities are clearly policy towards foreigners and immigration, internal security, and international relations. It is almost non-existent in activities relating to policies like agriculture and food, health, the economy, development policy, education, housing construction, or energy (Gensing, Bonnen and Masch 2018). This however does not damage the party's image among its followers. They are satisfied with the rightpopulist and scandalising discourse in parliament. The language is becoming increasingly brutal and a nationalist vocabulary is tending to become 'normal'.

$* * *$

The results of the Bundestag elections in 2017 revealed a structural dilemma which will continue to exist in the foreseeable future. There are now six fractions in parliament, so coalitions are inevitable. Two of the six parties (if CDU and CSU are counted as one party) are not accepted by the other parties as a government partner: at the left margin is Die Linke, because of its positions in foreign and especially security policy (e.g. its refusal to recognize NATO and operations of the Bundeswehr abroad), and at the right margin is the $\mathrm{AfD}^{10}$. The SPD only after long internal discussions and tensions agreed to form again a 'grand coalition', which seemed at that moment to be the lesser evil considering the alternative was new elections.

10 At the end of September the chief of the CDU fraction in the Saxonian diet did not exclude a coalition with the AfD after the elections in 2019, but this was fiercely rejected by CDU leaders, with Angela Merkel at the top. In the long run, however, a coalition of the CDU with the AfD does not seem to be excluded on the regional and local levels, especially in East Germany. 


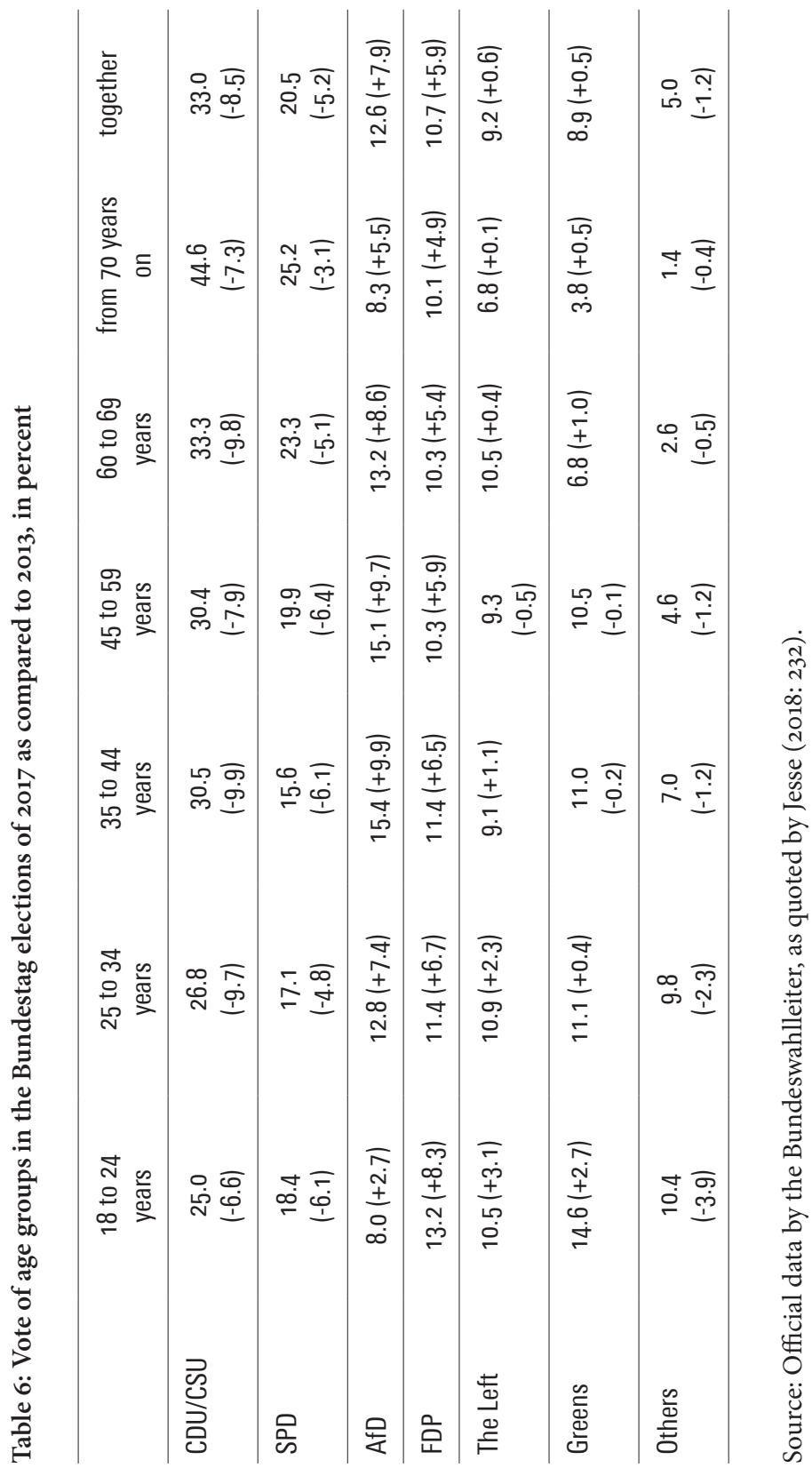


The profound changes in the German party system are visible when one compares the majority the four previous 'grand coalitions' had had. The first one, (1966-69) had 86.9 percent of the votes; in 2005 it was still 69.4; in 2013 fell to 56,8; and in 2017 was only 53,4 percent - hardly a 'grand' coalition any longer. Looking at the voting in 2017 by age groups a dramatic change is also evident. The former 'catch-all' parties (Volksparteien) CDU/CSU and SPD still deserve that name only among the 70 years old or older voters.

The long-term trend of a continuous fragmentation of the party system, which was interrupted in 2013 when the number of Bundestag fractions was reduced to four, seems to have returned. A closer look shows, however, that this is not an inevitable evolution due to economic and social development. Short-term factors, especially the migrant crisis, have played a decisive role. Couple of years ago protest voters preferred the left, especially in East Germany. How fluid this protest electorate is was underscored in the 2017 Bundestag elections. In several East Berlin constituencies where the AfD received results above average, many AfD-voters gave their first vote (for the direct seat for which the AfD had no chance) to the left (Berlin bleibt bei der Wahl gespalten 2017).

The answer to the question put in the title of this article is twofold. On one hand, the AfD has undoubtedly changed politics in Germany. On the other hand the rising-up of this party is the German version of the trends which have witnessed the emergence of populist parties in several countries: social divides and disintegration; diminishing responsiveness of the former 'catch all' parties, most of which have drifted toward the centre so that voters cannot recognize a clear profile; new cultural cleavages, leaving many people with a feeling of that their national identity is threatened; and specifically in the case of Germany the as yet incomplete East-West integration; as well as other factors. The two main cleavages in Germany concern cultural identity and the socio-economic divide. The alienation of many voters from the political class is not a process without remedy. It could be mitigated by programmes in policies which are sensitive for many people, such as housing for instance. Populists don't have answers to the problems which 
they are expounding and exposing, but are gaining advantages from the lack of answers by the 'established' political parties (political elites). The electorate is quickly reacting to the answers of political parties to new challenges. The figures in Table 5 show that the possibilities of growth for the AfD are limited. Whether further growth of the AfD can be stopped depends to a large extent on the ability of the political elites to regain their responsiveness to urgent problems which many people feel are being neglected ${ }^{11}$.

\section{References}

Adorno, T.W., Frenkel-Brunswik, E., Levinson, D.J. and Sanford, R.N. (1950). The Authoritarian Personality. New York: Harper \& Brothers.

'AfD überholt die SPD und wird zweitstärkste Kraft', Die Welt, 30.09.2018, available at https://www.welt.de/politik/deutschland/article181714198/Emnid-Umfrage-AfD-ueberholt-SPD-und-wird-zweitstaerkste-Kraft.html

AfD will Beobachtung verhindern, 11.09.2018, available at https://www.tagesschau.de/inland/afd-verfassungsschutz-123.html

Bebnowski, D. (2015). Die Alternative für Deutschland. Aufstieg und gesellschaftliche Repräsentanz einer rechten populistischen Partei. Wiesbaden: Springer.

Bei AfD-Jugendorganisation. Gauland: Hitler nur 'Vogelschiss' in deutscher Geschichte', Frankfurter Allgemeine Zeitung, 02.06.2018, available at http://www.faz.net/aktuell/politik/inland/gauland-hitler-nur-vogelschissin-deutscher-geschichte-15619502/vogelschiss-in-1000-jahren-15619521. html

Bender, J. (2017). 'Russlandkongress' der AfD. Alternatiwa dlja Germanii', Frankfurter Allgemeine Zeitung, 13.08.2017, available at http://www.faz. net/aktuell/politik/inland/afd-verteidigt-putin-auf-ihrem-russlandkongress-15149657.html

Berlin bleibt bei der Wahl gespalten, 25.09.2017, available at https://www. rbb24.de/politik/wahl/bundestag/beitraege/berlin-btw-ost-west-vergleich-hochburgen.html

11 Cf. the proposals made by Vehrkamp and Merkel (2018), 43-63. 
Bockenheimer, J.C. (2016). 'Ich habe versucht, den außenpolitischen Kurs der AfD zu verstehen - es war verstörend', Der Tagesspiegel, 17.06.2016, available at http://www.tagesspiegel.de/politik/gauland-hoecke-und-coich-habe-versucht-den-aussenpolitischen-kurs-der-afd-zu-verstehen-eswar-verstoerend/13706358.html.

Brähler, E., Kiess, J. and Decker, O. (2016). 'Politische Einstellungen und Parteipräferenz: Die Wähler/innen, Unentschiedene und Nichtwähler 2016', in Decker, O., Kiess, J. and Brähler E. (eds.), Die enthemmte Mitte: Autoritäre und rechtsextreme Einstellung in Deutschland. Leipzig: Psychosozial-Verlag, 67-94.

Bundestagswahl 2013. Das Wahlprogramm der Alternative für Deutschland (2013), available at https://www.focus.de/politik/deutschland/bundestagswahl-2013/bundestagswahl-2013-das-wahlprogramm-der-alternative-fuer-deutschland_aid_1039346.html.

Bundesverfassungsgericht. Urteil vom 17. Januar 2017 - 2 BvB 1/13, available at https://www.bundesverfassungsgericht.de/SharedDocs/Entscheidungen/ DE/2017/o1/bs20170117_2bvbooo113.html.

Carstens, P. (2013). 'Außenpolitisches Konzept. AfD nimmt sich Bismarck zum Vorbild', Frankfurter Allgemeine Zeitung, 12.09.2013, available at http://www.faz.net/aktuell/politik/bundestagswahl/aussenpolitisches-konzept-afd-nimmt-sich-bismarck-zum-vorbild-12569281.html.

Decker, O., Kiess, J. and Brähler, E. eds. (2016). Die enthemmte Mitte. Autoritäre und rechtsextreme Einstellung in Deutschland. Leipzig: Psychosozial-Verlag; also available at https://www.boell.de/sites/default/files/ buch_mitte_studie_uni_leipzig_2016.pdf.

Decker, O., Kiess, J., Eggers, E. and Brähler, E. (2016). Die 'Mitte'-Studie 2016: Methode, Ergebnisse und Langzeitverlauf, in Decker, O., Kiess, J. and Brähler, E. eds. (2016). Die enthemmte Mitte. Autoritäre und rechtsextreme Einstellung in Deutschland. Leipzig: Psychosozial-Verlag, 23-66.

Decker, O. and Brähler, E. (2016). Ein Jahrzehnt der Politisierung: Gesellschaftliche Polarisierung und gewaltvolle Radikalisierung in Deutschland zwischen 2006 und 2016, in Decker, O., Kiess, J. and Brähler, E. eds. (2016). Die enthemmte Mitte. Autoritäre und rechtsextreme Einstellung in Deutschland. Leipzig: Psychosozial-Verlag, 95-136.

Die Erfurter Resolution - Wortlaut und Erstunterzeichner (2015), available at https://www.derfluegel.de/2015/03/14/die-erfurter-resolution-wortlautund-erstunterzeichner. 
Exner, U. (2018). 'Gerade mal 175 Leute kommen zur Anti-Merkel-Demo', Die Welt 06.09.2018, available at https://www.welt.de/politik/article181434750/ Hamburg-Gerade-mal-175-Leute-kommen-zur-Anti-Merkel-Demo.html.

Gauland bezeichnet 'Vogelschiss'-Äußerung als 'politisch unklug', 09.06.2018, available at https://www.welt.de/politik/deutschland/article177262066/ AfD-Chef-Gauland-bezeichnet-Vogelschiss-Aeusserung-als-politisch-unklug.html.

'Gauland provoziert mit Äußerung zur Nazizeit', Zeit-online, 14.09.2017, available at http://www.zeit.de/politik/deutschland/2017-09/afd-alexander -gauland-nazi-zeit-neubewertung.

Gensing, P., Bonnen, Ch. and Masch, O. (2018). AfD im Bundestag. Top-Thema Ausländer, 24.09.2018, available at http://faktenfinder.tagesschau.de/ inland/afd-bundestag-bilanz-101.html.

'Gesetz zur Änderung des Grundgesetzes (Artikel 21) vom 13. Juli 2017'. BGBl. 2017, I: 47, available at http://www.jura.fu-berlin.de/fachbereich/einrichtungen/oeffentliches-recht/emeriti/pestalozzac/Ressourcen/o-Grundgesetz-Aend-Art_-21-GG-Juli-2017-BGBl-I-S_-2346.pdf.

Gürgen, M., Jakob, Ch. and am Orde, S. eds. (2018). Netzwerk AfD. Die neuen Allianzen im Bundestag. Frankfurt am Main: Otto-Brenner-Stiftung, available at https://www.otto-brenner-stiftung.de/fileadmin/user_data/ stiftung/o2_Wissenschaftsportal/o3_Publikationen/AP30_Netzwerk_AfD. pdf.

Hertel, G. (1998). Die DVU - Gefahr von Rechtsaußen. München: Hanns-Seidel-Stiftung, available at https://www.hss.de/fileadmin/migration/downloads/aa12.pdf.

Höcke-Rede im Wortlaut: 'Gemütszustand eines total besiegten Volkes', 19.01.2017, available at https://www.tagesspiegel.de/politik/hoecke-redeim-wortlaut-weizsaeckers-rede-zum-8-mai-1945-war-gegen-das-eigenevolk/19273518-3.html.

Inglehart, R. (1977). The Silent Revolution. Changing Values and Political Styles among Western Publics. Princeton / New Jersey: Princeton University Press.

Jachnow, J. (2013). 'What's become of the German Greens?', New Left Review, 18.09.2018, 81, 25-117, available at https://newleftreview.org/II/81/joachimjachnow-what-s-become-of-the-german-greens.

Jesse, E. (2018). 'Die Bundestagswahl 2017 im Spiegel der repräsentativen Wahlstatistik', Zeitschrift für Parlamentsfragen, 49:2, 223-242. 
'Katholiken-Präsident: AfD ist rechtsradikal. Interview with Thomas Sternberg', Neue Osnabrücker Zeitung, 08.09.2018, available at https://www. presseportal.de/pm/58964/4055729.

Leggewie, C., Lichtl, J. and Meier, H. (2017). 'Hohe Hürden' sehen anders aus. Das abermalige Verbotsverfahren gegen die NPD. Kritik des Urteils (Teil 3)', Recht und Politik, 2/2017, 145-173.

Lepsius, M. R. (1993). Demokratie in Deutschland. Historisch-soziologische Konstellationsanalysen. Ausgewählte Aufsätze. Göttingen: Vandenhoeck \& Ruprecht.

Manifesto for Germany. The Political Programme of the Alternative for Germany (2016), available at https://www.afd.de/grundsatzprogramm.

Niedermayer, O. (2008). 'Das fluide Fünfparteiensystem nach der Bundestagswahl 2005', in Niedermayer, O. (ed.), Die Parteien nach der Bundestagswahl 2005. Wiesbaden: Springer.

Niedermayer, O. (2017). Mitgliederentwicklung der Parteien, available at http://www.bpb.de/politik/grundfragen/parteien-in-deutschland/zahlen-und-fakten/138672/mitgliederentwicklung.

Richter, Ch. and Bösch, L. (2017). Demokratieferne Räume? Wahlkreisanalyse zur Bundestagswahl 2017. Jena: Amadeu Antonio Stiftung, available at https:/www.amadeu-antonio-stiftung.de/aktuelles/2017/ studie-demokratieferne-raeume-wahlkreisanalyse-zur-bundestagswahl-2017.

Rippl, S., Baier, D. and Boehnke, K. (2007). Europa auf dem Weg nach rechts? Die EU-Osterweiterung und ihre Folgen für politische Einstellungen in Deutschland, Polen und der Tschechischen Republik. Wiesbaden: Springer.

Rosenfelder, J. (2017). 'Die Programmatik der AfD: Inwiefern hat sie sich von einer primär euroskeptischen zu einer rechtspopulistischen Partei entwickelt?', Zeitschrift für Parlamentsfragen, 48:1, 123-140.

Ruhose, F. (2019). Die AfD im Deutschen Bundestag. Zum Umgang mit einem neuen politischen Akteur. Wiesbaden: Springer.

Sachverständigenrat deutscher Stiftungen für Integration und Migration (2018). Parteipräferenzen von Zuwanderinnen und Zuwanderern: Abschied von alten Mustern. Berlin: Kurzinformation des SVR-Forschungsbereichs 2018-2, available at https://www.svr-migration.de/wp-content/ uploads/2018/09/SVR_Parteipraeferenzen_2018.pdf.

Schroeder, W., Weßels, B., Neusser, Ch. and Berzel, A. (2017). Parlamentarische Praxis der AfD in deutschen Landesparlamenten. Discussion Paper 
SP V 2017-102. Wissenschaftszentrum Berlin für Sozialforschung, available at https://bibliothek.wzb.eu/pdf/2017/v17-102.pdf.

Vehrkamp, R. and Merkel, W. (2018). Populismusbarometer 2018. Populistische Einstellungen bei Wählern und Nichtwählern in Deutschland 2018. Wissenschaftszentrum Berlin für Sozialforschung / Bertelsmann Stiftung, available at https://www.bertelsmann-stiftung.de/fileadmin/files/BSt/Publikationen/ GrauePublikationen/ZD_Studie_Populismusbarometer_2018.pdf.

Vorländer, H., Herold, M. and Schäller, S. (2016). PEGIDA. Entwicklung, Zusammensetzung und Deutung einer Empörungsbewegung. Wiesbaden: Springer.

Wagner, B. (2018). 'Vertuschte Gefahr: Die Stasi \& Neonazis', in Dossier Stasi. Berlin: Bundeszentrale für politische Bildung, available at http://www.bpb. de/geschichte/deutsche-geschichte/stasi/218421/neonazis.

Waibel, H. (1996). Rechtsextremismus in der DDR bis 1989. Köln: Papy-Rossa-Verlag.

'Wer die Rechtspopulisten wählt und warum. Erstaunliche Umfrage-Details über die AfD'. Bild-Zeitung, 01.09.2018, available at https://www.bild.de/ politik/inland/politik-inland/erstaunliche-umfrage-details-ueber-die-afdund-was-sie-bedeuten-57168306.bild.html.

Wochenimpuls: Kardinal Woelki: Keine Alternative für Deutschland (09.09.2018), available at https://www.domradio.de/video/kardinal-woelki-keine-alternative-fuer-deutschland.

Klaus Ziemer is a professor of political science and a contemporary historian at Cardinal Stefan Wyszynski University in Warsaw. Before he had been a professor at the University of Trier. He received his PhD and 'habilitation' at the University of Heidelberg. From 1998 to 2008 he was director of the German Historical Institute in Warsaw. His main publications in German, English and Polish concern problems of political and socio-economic transformation in East Central Europe, contemporary history of Poland, Polish-German relations after WWII and coming to terms with the heritage of totalitarian and authoritarian regimes in Europe.

\section{Klaus Ziemer}

Cardinal Stefan Wyszynski University in Warsaw

Faculty of History and Social Sciences

ul. Woycickiego 1/3, 01-938 Warszawa, Poland

e-mail: ziemer@uni-trier.de 